\title{
"You will never understand": the monopoly of the place of speech through cultural trauma narratives in Brazil
}

\author{
Vitor Blotta
}

RESUMO: O objetivo deste artigo é analisar estudos e narrativas sobre trauma cultural para entender as características básicas de auto-compreensões conservadoras e reacionárias, que podem ser chamadas de "monopólios do lugar de fala". Por causa de seu caráter radical, acredito que narrativas de traumas culturais, como a literatura de testemunho e romances gráficos podem dar acesso às principais características desses monopólios e a maneiras de criticá-los. Esses elementos são a inacessibilidade, o deslocamento e a repetição tardia, as quais são então utilizadas neste artigo para analisar literatura de ficção e não-ficção e romances gráficos sobre a dituradura militar Brasil, como "K" de Bernardo Kucisnki (2013) e "Notas de um Tempo Silenciado", de Robson Vilalba (2014).

PALAVRAS-CHAVE: Narrativas de traumas culturais; monopólio do lugar de fala; produtos culturais; ditadura militar no Brasil

\begin{abstract}
The aim of this article is to analyse cultural trauma studies and narratives in order to understand the basic features of conservative and reactionary self-understandings in contemporary societies, which can be called "monopolies of the place of speech". Because of their extreme and radical character, I believe that cultural trauma narratives, such as testimony literature and graphic novels can give access to the most important traits of these monopolies, and to ways of countering them. These elements are inaccessibility, displacement and belatedness, which are then used to analyse contemporary fiction and non-fiction literature and graphic novels on the Brazilian Dictatorship, such as Bernardo Kucinsky's K (2013) and others.
\end{abstract}

KEYWORDS: Cultural trauma narratives; monopoly of the place of speech; cultural works; Brazilian dictatorship 


\section{THE AMALGAM OF SUFFERING: CULTURAL TRAUMA AND THE MONOPOLY OF THE PLACE OF SPEECH}

Cultural trauma studies indicate a new approach to the history of human conflicts. Since the Nuremberg trials and other transitional policies that used representations of the atrocities committed during the Second World War, human rights movements have tried to shift the debate on winners as the writers of history, to the narratives of the victims and their experiences of suffering. ${ }^{1}$ The focus is not on the heroic actions and battles anymore, but on tragic events involving innocent people from all sides of armed conflicts and other disasters.

Quoting Fassin and Rechtman from Empire of Trauma (2009), ${ }^{2}$ Humphrey states that this shift has turned history "tragic", in the sense of a collective effort to cope with, and understand psychological traumas of the past. And as these narratives and their claims for reparation gain public recognition, traumatic events start to embody the collective memories and identities of specific cultures, henceforth named cultural traumas.

The strength of this historical shift comes from the idea that the narratives of those who suffered acts of extreme violence have a compelling authenticity and truth-tracking potential, as well as a capacity to negatively embody humanitys highest moral values. This combination of cognitive, moral and expressive elements is clear with Humphrey's recovery of Paul Ricouer's argument in The Just (2000), ${ }_{4}^{4}$ to whom trauma reveals the "affective roots of injustice".

The suffering of victims, however, do not produce undisputable narratives. Current public debates on human rights in many countries also reveal collisions between narratives and representations of different victims, with efforts to defend who is more "justly victimized". Discourses against human rights activists often accuse them of defending specific victims over others. According to Humphrey, people relate to the narratives of suffering with a "filter and moral economy of trauma". Most become

1. Cf. humphrey, M. “The Politics of Trauma. Inaugural Lecture to the Arts Association”. Sidney, 2010; MEEK, A. Trauma and Media. Theories, Histories, and Images. London: Routledge, 2010.

2. FASSIn, Didier; RECHTMAN, Richard. The Empire of Trauma: an Inquiry into the Condition of Victimhood. Princeton; Oxford: Princeton University Press, 2009.

3. humphrey, M. "The Politics of Trauma. Inaugural Lecture to the Arts Association", cit., p. 38. 4. Ricoeur, Paul. The Just. Trans. David Pellauer. Chicago and London: The University of Chicago Press, 2000.

116 BLOTTA, Vitor. "You will never understand": the monopoly of the place of speech 
more affected by sites and material evidence, by those who are more similar to them, or by ritualized practices around traumatic experiences. ${ }^{5}$ With the multiplication of narratives on traumatic events, sites of memory and their visibility through electronic and digital communication, with the possibility of a complacent distant suffering, ${ }^{6}$ these inclinations may be intensified.

A possible explanation is that because of the pragmatic and resource limitations of human rights oriented attitudes and policies, the positions towards victims becomes based on their individual characteristics, rather than the common traces of their traumatic experiences with general notions of humanity and justice. Thus, it seems that even though trauma narratives are comprised of radical "amalgams" of moral, cognitive and expressive elements, the way the last two are mobilized is determinant to current positions towards human rights policies.

\section{IN BETWEEN TWO SIDES TO CULTURAL TRAUMA NARRATIVES}

This idea that narratives of trauma bare a historical authenticity derives from theories of cultural trauma and of history as trauma, which are inspired by Freud's Civilization and Its Discontents, ${ }^{7}$ and according to Meek, ${ }^{8}$ by erroneous readings of Benjamin's "Theses on the Philosophy of History" 9 and Adorno's reflections on culture after Auschwitz. ${ }^{10}$ Meek argues that whilst Freud's work renders culture as neurotic responses to the immediacy of a traumatic history, ${ }^{11}$ Benjamin and Adorno were not actually discarding

5. humphrey, M. "The Politics of Trauma. Inaugural Lecture to the Arts Association", cit., pp. 52-3.

6. воLTAnsky, L. Distant Suffering. Morality, Media and Politics. Cambridge: Cambridge University, 2004.

7. FREUD, S. Civilization and Its Discontents. London: Penguin, 2002 [1930].

8. Meek, A. Trauma and Media. Theories, Histories, and Images, cit.

9. Benjamin, W. "Theses on the Philosophy of History", 1968.

10. RICHARdSON, A. "The Ethical Limits of Holocaust Representation". ESharp. Borders and Boundaries. 5, 2005.

11. It is important to note that there are less deterministic readings of Freud's social works, such as in Habermas's Knowledge and Human Interests (2002). In his reflections on psychoanalysis as a critical science, Habermas highlights that though Freud reckoned institutions as neurotic responses to repression of desire, he also acknowledged the possibility of 'constructive social neuroses', using the ideas behind French Revolution as examples. This subtle point does not override, however, > 
possible forms of narrating trauma, but were rather signalling to the limits of a culture that had itself resulted in unspeakable tragedies. ${ }^{12}$

Meek is worried about an academic opposition between more "traditional narratives" of trauma and those from audiovisual media. If, on one hand, firstly photographs and later on testimony films and literature were seen as giving access to "bare" experiences of trauma, hence of historical truth, on the other, the multiplication of such narratives in the mass media, especially in audiovisual format, began to be considered as inevitably leading to voyeurism, moral numbness and political disengagement in audiences and spectators.

The way that some approaches to cultural trauma can surpass this dichotomy is by acknowledging the limits of language to reproduce or authentically represent trauma, but also its potential to continue pointing to its facts and moral relevance. By maintaining this uncomfortable position, they not only avoid a fall-back to ontological approaches that contemporary pragmatic philosophy ${ }^{13}$ has struggled to criticize, but also shed light on the limits of perception and "factual data" as immediate indicators to history and normativity.

I believe that some of the works that maintain this middle position in cultural trauma theory are those of Richardson (2005), ${ }^{14}$ Kilby (2007) ${ }^{15}$ and Meek (2010), ${ }^{16}$ who are focused on visual and media representations of trauma, and those of Seligmann-Silva (2003), ${ }^{17}$

$>$ the central argument of Civilization and its Discontents, but helps situate my approach to cultural trauma and the normative ideas proposed in the final part of this paper.

12. MeEK, A. Trauma and Media. Theories, Histories, and Images, cit.

13. I am referring here to "detranscendentalized" Kantian approaches, such as Wittgenstein's, Peirce's, Habermas's, and Forst's, as well as "deabsolutized" Hegelian approaches, such as Dewey's, Rorty's and Honneth's. I am still not sure whether agonistic approaches such as Chantal Mouffe's could be inserted in this latter category. My guess at the moment is that it should not, for even though Hegelian in some senses, Mouffe recovers ontological concepts, such as antagonism and hegemony.

14. RIChardson, A. "The Ethical Limits of Holocaust Representation", cit.

15. KILBY, J. Violence and the Cultural Politics of Trauma. Edinburgh: Edinburgh University, 2007.

16. MEEK, A. Trauma and Media. Theories, Histories, and Images, cit.

17. SELIGMANN-SiLVA, M. "O testemunho: entre a ficção e o real". In: (Org.). História, memória, literatura. Campinas: Ed. Unicamp, 2003.

118 - BLOTTA, Vitor. "You will never understand": the monopoly of the place of speech 
Ginzburg (2010), ${ }^{18}$ and Caruth (1996), ${ }^{19}$ who work more with literary narratives. Despite many differences and also some critiques between each other, all of them seem to mobilize the preceding works from Freud, Benjamin and Adorno in non-absolutist manners, which is why they were useful for the research resulting in this paper.

In order to discuss how the insights from these theories help characterize the phenomena of the monopoly of the place of speech, as well as systematize some criteria for the subsequent analysis of the cultural works, I will focus on what I believe are the most important features of trauma as discussed in Cathy Caruth's Unclaimed Experience (1996), and explain how they promote a shutting off one one's references from others. After that, the analytical framework of the paper will include literary techniques from SeligmannSilva's and Ginzburg's ${ }^{20}$ works on testimony literature, along with some traits of visual media narratives of trauma from Meek, Kilby, and Richardson, followed by classical and recent works on comics, such as Eisner's (1985), ${ }^{21}$ Mcloud's (1993) ${ }^{22}$ and Giddens's (2015). ${ }^{23}$

\section{THE THREE ELEMENTS OF TRAUMA AND THE SEASHELL METAPHOR}

Cathy Caruth is considered one of the most important theorists in the area of cultural trauma. Her works Trauma: Explorations in Memory (1995), ${ }^{24}$ and Unclaimed Experience. Trauma, Narrative and History (1996) helped set the intersections of history, literature, psychology and psychoanalysis that are peculiar of the area. Caruth argues with Freud that trauma is an experience that cannot be fully grasped by the victim, and its symptoms only emerge in belated and recurring moments. Therefore, the more

18. GinZburg, J “Escritas da tortura”. Diálogos Latino-Americanos, http://lacua.au.dk/fileadmin/ www.lacua.au.dk/publications/3_di_logos_latinoamericanos/6tortura-ginzburg, 2010.

19. CARUth, C. Unclaimed Experience: Trauma, Narrative and History. London: John Hopkins, 1996. 20. GinZburg, J.; SEligmann-Silva, M. (Orgs.). Escritas da violência: 1, O testemunho, Rio de Janeiro: 7Letras, 2012; GINZBURG, J.; SELIGMANN-SILVA, M; FOOT HARDMAN, F. (Orgs.). Escritas da violência: 2, Representações da violência na história e na cultura contemporâneas da América Latina. Rio de Janeiro: 7 Letras, 2013.

21. Eisner, W. Comics and Sequential Art. Tamarc: Poorhouse, 1985.

22. Mccloud, S. Understanding Comics: the Invisible Art. New York: Harper Collins, 1993.

23. GIDDENS, T. (ed.). Graphic Justice: Intersections of Comics and Law. London: Routledge, 2015.

24. CARuth, C. Trauma: Explorations in Memory. London: John Hopkins, 1995. 
"indirect" narratives of literature and arts can better represent it. Or rather, trauma "speaks through" these works.

This inaccessibility of trauma is criticized by Meek (2010), ${ }^{25}$ who argues that it reveals an essentialist conception of the phenomena. Hence, any further representation of it would result "untruthful". However, this thesis can only be defensible if Caruth's concept of reference is equivalent to an immediate perception, which is not the case. By valuing continuous narratives as ways through which trauma "cries out", Caruth avoids both the essentialization of reference and of perception. While this inaccessibility reveals the cognitive limits of representing trauma, it also drives attention to how historical process itself is comprised of a belated and recurring process of diversified cultural referencing and narrating.

Aside from inaccessibility and belatedness as symptoms of trauma, a form of displacement would also characterize it, as the unending connection of the victim's identity and survival with the lives and identities of those who died. This element has a deep ethical dimension, for it can surface in strong feelings of moral guilt or shame, in the incompleteness of identity, and in the incapacity of sharing the same moral spaces with others. Given that through trauma one's life is permanently attached to another's death, even though negatively, this attachment reveals the underlying moral connections between individuals.

The combination of these three elements of trauma, inaccessibility, belatedness and displacement, with their respective cognitive, cultural and moral dimensions, form the amalgam of the victim's suffering, as well reveal the basic traits of the monopolization of the place of speech. That is why trauma narratives can be as compelling for those who share similarities, as they are for shutting oneself off from different others. Nevertheless, a full understanding of the traumatic event never seems to be available even to victim, witness or perpetrator, appearing only later in indirect and haunting representations. By losing sight of this inaccessibility and its indelible connection with distinct narratives, one's moral standpoint appears to shut itself off from others.

This process can be explained using the metaphor of a seashell. Although being seemingly shut from its environment, in a solid and hard carcass, its insides, where sometimes lays an untouched pearl, consist of the same matter of the sand outside. Moreover, if one tries to "listen" to the seashell by putting it close to the ear, the sounds

25. MEeK, A. Trauma and Media. Theories, Histories, and Images, cit. 
that appear come from it are actually the sounds produced inside the listener's body, and they can only be heard because of the seashell hollowness.

This metaphor helps explain both the basic features of the monopoly of the place of speech, and the deep-seated reciprocities that remain between different individuals and groups, even after traumatic events. It is only logical to assume that the stronger the trauma or the reasons driving this monopolization of one's references, the more difficult it will be for one to realize that historical truth can only be reached through the continuous inter-change of indirect narratives to facts, which involve affective engagement. The same counts for morality, which can only ascertain its validity once it acknowledges the potential validity of contrasting moralities.

\section{LITERARY TECHNIQUES FOR THE ANALYSIS OF TRAUMA NARRATIVES}

Ginzburg's and Seligmann-Silva's perspectives on cultural trauma and testimony literature confirm Caruth's basic elements of trauma and their cognitive, moral and affective aspects, and provide important tools for the analysis of the monopolies of the place of speech that are formed after traumatic experiences. Despite the considerable differences, Ginzburg considers European and Latin American testimony literatures to be examples of what Benjamin calls "politicization of aesthetics", that is, a reconnection of art and ethics through a choice of thematizing social exclusion.

Differently from what suggests Meek (2010) when criticizing Freud's concept of "unconscious" as a negative universalization of the western bourgeois individual, Ginzburg affirms that testimony literature "problematizes the place from where the subject of enunciation speaks". ${ }^{26}$ By giving voice to the excluded and his or her experience of trauma, this literature is performatively pointing to the seemingly ever-lacking identity of the modern subject, which is formed through an intersection of many external forces.

In a similar approach, Seligmann-Silva ${ }^{27}$ argues that testimony literature stands between attempts of "literalization" and "fragmentation", in other words, the striving for authentic representations of the traumatic events and the acknowledgment of its

26. Ginzburg, J. “Escritas da tortura”, cit., p. 3.

27. SeligmanN-Silva, M. “O testemunho: entre a ficção e o real”, cit. 
incapacity of linguistic representation. This proposition should not lead to the conclusion that a trauma that is labelled as such is absolute, and therefore an indisputable phenomenon. By stating that "language is a priori loss", Seligmann shows a non-absolutist and Wittgensteinian approach. For him trauma, as anything in the "objective world", is only accessible through the limits of language.

In terms of literary techniques and their ethical implications, Seligmann concedes that trauma narratives run the risk of producing a "fundamentalism of memory". ${ }^{28}$ This would lead the work to fall in the "uncontrollable path of an aesthetics of vengeance", ${ }^{29}$ which could result either from a very political piece or an attempt of giving an excessively objective, linear and chronological narrative of traumatic events.

This leads me to believe that, conversely, a "moral fundamentalism" can also occur if the narratives are excessively "one-sided", or dichotomist to a point that they do not leave any space for considering the other's moral point of view. Of course the extent of this will depend on the specific experiences and perspectives, but as morally demanding as it is to give voice to the victims of atrocities, it is also important not to portray perpetrators as the personification of "pure evil". This should not mean to avoid describing wrongful or "twisted" moralities, or the extent to which a system's engineering leads one to lose any moral connection with the other whatsoever, such as Arendt's ${ }^{30}$ analysis of Eichmann.

The position of the narrator and the combination of realism with more fictional and metaphoric and narratives can help the writer to shift between these two excesses, maintaining thereby a certain predominance of the literary form over presumably objective reporting or propaganda pieces. These cognitive and ethical crossovers and the adequate application of these techniques impact the quality of the trauma narrative, as well as its ability to reveal monopolies of the place of speech and the conditions for their critique.

\footnotetext{
28. Id., p. 3 .

29. Id., p. 7 .

30. ARENDT, H. Eichmann in Jerusalem. A Report on the Banality of Evil. New York: Penguin Books, 2006.
} 
Audiovisual productions show an even more radicalized divide between "bare" and "indirect" representations of trauma, mainly after the so-called "iconic turn" during the second half of the twentieth century. ${ }^{31}$ The belief that photography and later on testimony films and documentaries gave direct access to experiences of trauma is now strengthened with "real time" coverages and "real life" accounts of events that overflow distinct media outlets, such as the September 11, 2001 attacks to the World Trade Center. On the other side, the multiplication of trauma narratives also opens way for more indirect accounts, which generate strong critiques and reactions from different groups, as against Scorcese's The Last Temptation of Christ (1988) and Spielberg's Chindler's List. ${ }^{32}$

This greater divide in audiovisual narratives of trauma has produced a critical academic literature denouncing the disengaging, depressive and voyeuristic tendencies generated on spectators, even though some believe that moral and political actions can still be drawn from them..$^{33}$ Others suggest that though spectators are not passive towards these trauma representations, for they interpret and engage psychologically with them, the selectivities of media outlets can explain why some narratives are chosen over others, promoting new forms of exclusion. ${ }^{34}$

The power of images in representing trauma is connected to Freud's first theories on the iconic language of the unconscious. Because dreams would be impressions and enlargements of traumas and desires, Freud used the development of the photograph in a darkroom as an analogy of how its images would be revealed - from darkness to light. The technique of studying dreams was later replaced by free association as a way to access the unconscious and rationalize it. However, this does not mean that verbal language can represent trauma better that images. On the contrary, the traumatic elements

31. horkheimer, M.; adorno, T. W. Dialética do Esclarecimento. Fragmentos filosóficos. Rio de Janeiro: Jorge Zahar, 1985; HABERMAs, 2003; DEBORD, Guy. A sociedade do espetáculo. Rio de Janeiro: Contraponto, 1997; BUCCI, E. Televisão-objeto: a crítica e suas questões de método. Tese (Doutorado em Ciências da Comunicação). São Paulo, Escola de Comunicação e Artes da Universidade de São Paulo, 2002; HABERMAS, 2006a.

32. RICHARDSON, A. “The Ethical Limits of Holocaust Representation”, cit.

33. Sontag, S. Regarding the Pain of Others. New York: Picador, 2003; Boltansky, L. Distant Suffering. Morality, Media and Politics, cit.; Kilby, J. Violence and the Cultural Politics of Trauma, cit. 34. MEeк, A. Trauma and Media. Theories, Histories, and Images, cit. 
of inaccessibility, displacement and belatedness, associated with strong emotions of distress shows the importance of images to represent trauma. However, even though representations are more iconic and affective than verbal and cognitive, this doesn't mean that they give bare access to trauma. ${ }^{35}$

This leads us to conclude that iconic language plays an important role in representing trauma, because of its plastic ability to go from the aesthetic shocks of seemingly "direct" representations, to the continuously fragmented, ominous and surreal recurrences of traumatic memories. Anna Richardson's analysis of the "shower scene" in Spielberg's Schindler's List ${ }^{36}$ demonstrates that by using indirect representations, images in films can pay tribute to the injustice and barbarity of the Holocaust without falling to the wrong attempt of portraying it "as it actually happened", thereby staying faithful to the characteristics of trauma.

A form of art that can have a strategic position in creating a balance between direct and indirect representations of trauma is comics or graphic novels. With its balance between text and images, it can advocate a midway position amongst the textual and the iconic, the rational and the emotional, questioning the limits of rationality and its unalienable connections with visibility and affections. ${ }^{37}$ This position of comics can help reveal the element of inaccessibility that is peculiar of trauma, as well as the limits of language to apprehend the objective world.

The elements of inaccessibility and displacement in trauma can be approached by what authors such as Will Eisner (1985) and Scott McCloud (1993) $)^{38}$ call the "gutter effect", which according to them occurs when the reader's imagination "fills the gutter" between frames when interpreting the narrative. The comics Gestalt, the idea of an incommensurable void that can only be "filled" with the engaging interpretation of the reader is similar to the incompleteness of trauma narratives and its undeletable connection with the references of a loss or an opposing other. In this sense, the medium of comics seems to "cry out" for the reader's engagement even more than in solely textual or visual narratives.

\footnotetext{
35. Id.

36. RICHARDSON, A. “The Ethical Limits of Holocaust Representation”, cit.

37. Giddens, T. (ed.). Graphic Justice: Intersections of Comics and Law, cit.

38. eISNER, W. Comics and Sequential Art, cit.; McCloud, S. Understanding Comics: the Invisible Art, cit.
} 
The belated character of trauma can be related to the ever-changing formats and narratives of comics. With satire and exaggerations, trauma can be indirectly and affectively revealed, provoking discomfort as well as critique and identification. With more or less detailed drawings, there is a chance to alleviate as much as to draw attention to the harshness of events. The use of metaphoric figures and the possibility of changing visual and character perspectives are also representative of the element of displacement in cultural trauma, for they can determine as much as problematize "us and them" distinctions. The contrasts between text and images can also help reveal some situations that cannot be represented in written narratives.

The different genres and formats that are nowadays produced in the medium of comics, such as cartoons, satirical narratives, biographies and historical works, comics journalism and others are also examples of the medium's capacity to reinvent itself and push the boundaries of representation. Critically acclaimed works such as Maus by Art Spiegelman (1980-1991), ${ }^{39}$ and Persepolis, by Marjane Satrapi (2000), ${ }^{40}$ and more recently Joe Sacco's bibliography are proofs that the medium is able to offer important if not fundamental representations of cultural trauma narratives. In Brazil works from comics authors like Fábio Moon and Gabriel Bá and Marcelo Quintanilha give new breadth to the country's cultural sphere.

\section{II. "SEEING THROUGH THE SHELL": ANALYSIS OF BRAZILIAN CULTURAL TRAUMA NARRATIVES}

The empirical analysis of the works will approach Brazilian literature and comics on the Military Dictatorship. The idea is not to go through their narratives in detail, but to make general remarks on how their characteristics might reveal monopolies of the place of speech, as well as ways to counter them. The analytical framework discussed before consists of the cultural trauma categories Inaccessibility, Belatedness, and Displacement, from which specific criteria on literary (literalization and fragmentation) and comics works (gutter-effect, changing perspectives and visual metaphors) were drawn, as systematized below:

\footnotetext{
39. SPIegelman, Art. Maus: a survivor's tale. New York: Pantheon Books, 1986-1991, 2 vols.

40. SAtrapi, Marjane. Persepolis. Paris : L’Association, 2000; New York: Pantheon Books, 2003.
} 


\begin{tabular}{|l|l|l|}
\hline $\begin{array}{l}\text { CULTURAL TRAUMA } \\
\text { NARRATIVES }\end{array}$ & LITERATURE & COMICS \\
\hline $\begin{array}{l}\text { Inaccessibility } \\
\text { (cognitive dimension) }\end{array}$ & $\begin{array}{l}\text { Between literalization and } \\
\text { fragmentation. } \\
\text { Avoiding fundamentalism } \\
\text { of memory. }\end{array}$ & $\begin{array}{l}\text { Gutter effect - importance } \\
\text { of context and reader. } \\
\text { Between overly realistic } \\
\text { and indirect. }\end{array}$ \\
\hline $\begin{array}{l}\text { Belatedness } \\
\text { (aesthetic dimension) }\end{array}$ & $\begin{array}{l}\text { Between realism and fictionality } \\
\text { (objective and metaphoric). }\end{array}$ & $\begin{array}{l}\text { Visual metaphors: satiric and } \\
\text { critical to compelling and } \\
\text { heartfelt, contrast text and image. }\end{array}$ \\
\hline $\begin{array}{l}\text { Displacement } \\
\text { (moral dimension) }\end{array}$ & $\begin{array}{l}\text { Position of the narrator and } \\
\text { character construction. } \\
\text { Avoiding fundamentalism } \\
\text { of morality. }\end{array}$ & $\begin{array}{l}\text { Change of perspectives or } \\
\text { one-sided and dichotomist } \\
\text { representations. }\end{array}$ \\
\hline
\end{tabular}

\section{BRAZILIAN POST-DICTATORSHIP LITERATURE}

The many narratives of crimes during the dictatorship in Brazilian literature are well represented by Bernardo Kucinsky's K: relato de uma busca (K: report of a search), ${ }^{41}$ published in 2013, thirty years after the events told on the book occurred. Within the many examples of this testimony literature in Brazilian arts and social sciences, such as Brasil nunca mais (Brazil, Never More, 1985) by Dom Paulo Evaristo Arns, Henry Sobel and Jaime Wright, ${ }^{42}$ Batismo de sangue (Blood Baptism, 1982) by Frei Beto, ${ }^{43} \mathrm{O}$ Que é Isso, Companheiro? (What is This, Comrade? 1979), by Fernando Gabeira, ${ }^{44}$ Kucinsky's K stands out for its raw language and capacity to capture elements of inaccessibility, displacement, and belatedness, such as the surreal dimension of reality that overcomes the character's life, the recurring feelings of guilt and unending connection of the untraced

41. KUCINSKI, Bernardo. K. São Paulo: Expressão Popular, 2013; translated by Sue Branford, with drawings by Enio Squeff. London: Latin America Bureau, 2013.

42. ARNS, Paulo Evaristo; SOBEL, Henry; Wright, Jaime. Brasil, nunca mais. Petrópolis: Vozes, 1985.

43. ветто, Frei. Batismo de sangue: os dominicanos e a morte de Carlos Marighella. Rio de Janeiro: Civilização Brasileira, 1982.

44. Gabeira, Fernando. O que é isso, companheiro?: depoimento. Rio de Janeiro: Codecri, 1979; São Paulo: Companhia das Letras, 2012. 
forced disappearance of his daughter. The book is actually a semi-biographic, semi-fictional account of the author's personal experience as being the brother of this disappeared person, and witnessing their father's quest to find information about her.

One of the most impressive elements of Kucinsky's work is that in different chapters the narrator changes the perspective from the father and assumes the positions of the victim, the hijackers, the lover of the deputy known to have led the political police, as well as a woman who worked in the house were the kidnapped were taken. This technique provokes strong shifts from the positions of the victim and offenders, enabling the reader to really "step in the other's shoes". The author does not justify the actions, but at least acknowledges the humanity of the other, capturing his or her rationality. The effect is not only aesthetical, inserting the reader in a sometimes disconcerting experience, but is also avoids more stereotypical and external descriptions of the characters.

From all the books read in the research, $K$ was the one that used this resource of the narrator perspective to its full potential. In this case, aside from revealing that there are monopolies of the place of speech in all sides, such as in how the hijackers described the victim, and how the father lost contact with the ethical normalcy of his social groups, it allows a critique of these monopolies by showing that everyone a group's moral point of view still has connections with the others, even though relating negatively to them.

Two recent non-fiction works on the dictatorship were Mata! (which in Portuguese means both "woods", "forest", and the imperative of the verb "to kill") by Leonencio Nossa (2012) ${ }^{45}$ and A casa da vovó (Gradma's House), by Marcelo Godoy (2014). ${ }^{46}$ Both authors are journalists and have spent ten years each collecting historical information respectively on the Araguaia Guerrilla case, a long conflict between military forces and resistance movements in the Amazon region between the end of the sixties and beginning of the seventies, and the history of the Department of Information Operations (DOI-Codi), which during the same period was a centre of torture and political prisons of the Military Regime in São Paulo. Godoy won the Jabuti prize in 2015, the most important in the country, for non-fiction for A casa da vovó.

45. Nossa, Leonencio. Mata!: o major Curió e as guerrilhas no Araguaia. São Paulo: Companhia das Letras, 2012.

46. GODOY, Marcelo. A casa da vovó: uma biografia do DOI-Codi (1969-1991), o centro de sequestro, tortura e morte da ditadura militar: histórias, documentos e depoimentos inéditos dos agentes do regime. São Paulo: Alameda, 2014. 
Both works have high historical and memory value, which can be used for public awareness and investigations in truth commissions. Its descriptions of the investigations in the first person or as omniscient narrator are combined with transcriptions of interviews and more literary descriptions of the facts and characters. However, aside from when capturing testimonies such as Nossa's Mata! with Major Curió confessing participation in the Araguaia by comparing his life to the movie Apocalipse Now (Coppola, 1979), or the transcription in the opening of Godoy's book, with a "warning" he received from an anonymous caller telling him to stop the investigations, their less radical perspective shifts describe more the facts than the monopolies of the place of speech that were formed in the cases. In the end, they both seem to serve more in the fundamental quest for more information and documentation, rather than in revealing or promoting a deep reach into the ethical self-understanding of the actors involved in the cases.

This fact makes it clear that realistic accounts of the conflicts do not necessarily represent better the nature and effects of cultural traumas in experiences of war and dictatorship. The use of internal psychological discourse and objective descriptions, even though sometimes crossing the lines between non-fiction and fiction, is what enables an access to the ethical detachments and ambivalences of the monopoly of the place of speech. Here, the shifts between literality and fragmentation, realism and fictionality, narrative and historicization, and narrator perspectives are the strongest venues for revealing and criticizing the monopolies and its resulting antagonisms.

\section{BRAZILIAN POST-DICTATORSHIP COMICS}

Political humour titles and cartoons have been one of the main venues for comics in the Brazil since the XIX century, and it flourished during the 1964-1985 dictatorship, although struggling against censorship and persecutions. Publications such as $O$ Pasquim (1969-1991), with important authors such as Ziraldo, Henfil, Millôr Fernandes and Jaguar, are examples of the most important critical stances to the regime. Many authors that worked during the period have published compilations, such as Henfil's Diretas Já (Direct Elections for President Now!, 1984).47

47. HENFIL. Diretas já!. Rio de Janeiro: Record, 1984. 

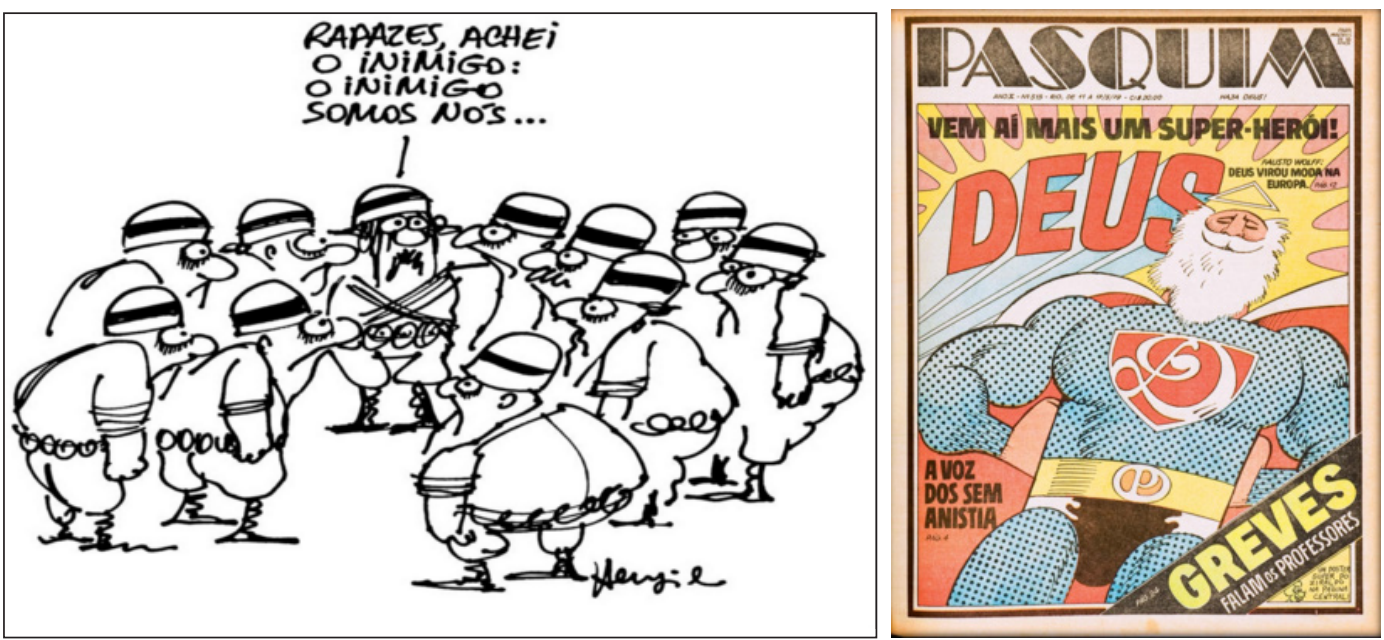

Despite the tradition of political satire cartoons the strong production during the dictatorship and, new albums on the subject only begin to appear again after the year 2000, most of them with the purpose of teaching the new generation about what happened during those times. The titles reviewed by the comics website www.universohq.com in 2014, fifty years after the military coup, show the diversity of genres in these new publications: from the adventure style series Subversivos (André Diniz, 1999-2000) and Ditadura no Ar (Raphael Fernandes and Abel, 2011); to the more historical and pedagogic Brasil - Ditadura Militar: Um livro para os que nasceram bem depois... (Brazil Military Dictatorship: a book for those who were born much later, Joana D'Arc Fernandes Ferraz e Diana Elene, 2014); 1968 - Ditadura Abaixo (Down with Dictatorship. Teresa Urban and Guilherme Caldas, 2008), A ditadura em quadrinhos (Sylvia Lucas, Colombo Ferraz and Caco Galhardo, 2014) and O Golpe de 64 (Oscar Pilagallo and Rafael Campos Rocha, 2014).

A highlight in this historical and pedagogical line of publications is Robson Vilalba's Notas de um Tempo Silenciado (Notes of a Silenced Time, 2015) ${ }^{48}$ winner of the Vladimir Herzog Prize for Journalism in the art category (2014). In this album, the author intersects historical and documented events with personal narratives from the people involved, in a strong "comics journalism" fashion, though never outside of

48. vilalba, Robson. Notas de um tempo silenciado. Porto Alegre: BesouroBox, 2015. 

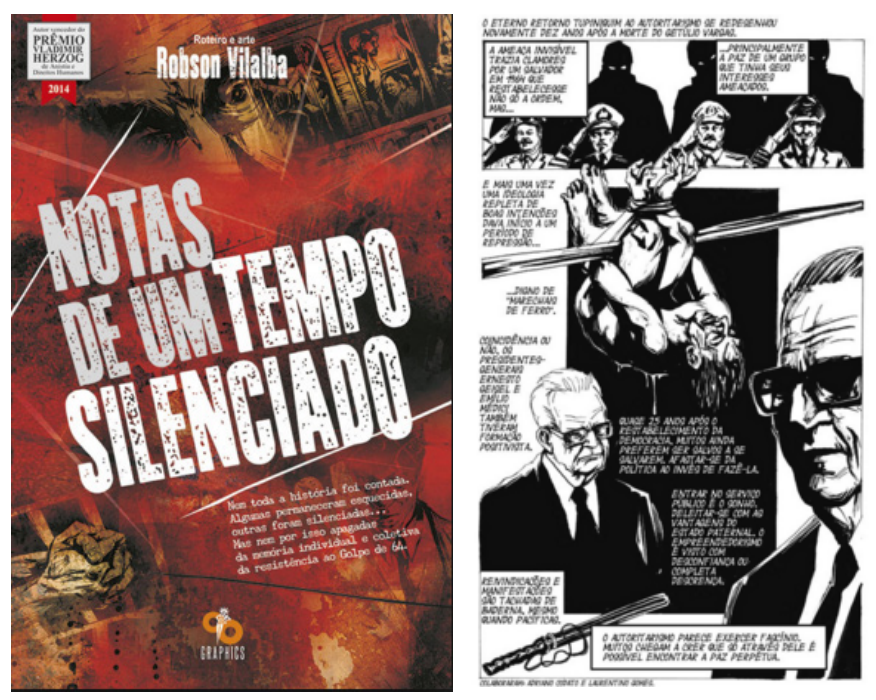

the omniscient narrator perspective. With an in-depth research, the work is able to picture not only well known events but important "untold stories", such as the destruction of indigenous villages in order to build the Itaipu dam in the seventies, as well as the life of Northern man Osvaldo Orlando da Costa, who studied engineering in the Southeast of Brazil and also in Eastern Europe, before becoming a fighter in the resistance to the militaries in the Araguaia region in the Amazon.

The artistic quality of the work prevents it from becoming overly informative, and the narrative elements pull the readers inside the stories, despite the omniscient narrator perspective. In the end, however, these narrative and artistic elements are not as strong as the more rationalistic and cognitive objectives of journalistic discovery that is present in the work. There are less dichotomist views towards the conflicts, but not to critical position-taking shifts that the comics medium may promote in certain narratives.

Another title that is not directly related to the military dictatorship, but may be representative of the monopolies of the place of speech that are formed in a culture of continuous social and political violence and corruption bred in the dictatorship is Luciano Cunha's O Doutrinador (2014 and 2015). It is the story of a former military soldier who becomes a "black bloc" assassin of corrupt politicians, gaining popular support, firstly produced for as an Internet comic and now translated to English as The Awakener. The title was recently reviewed in the UK newspaper 

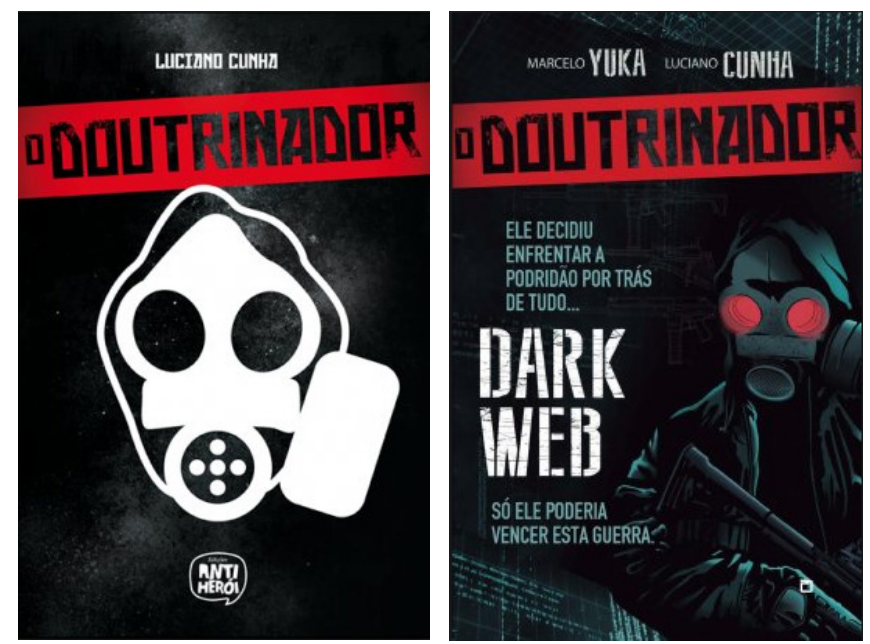

The Guardian ${ }^{49}$ as an expression of the radicalized political tensions in present Brazil. The comic is in its second edition (the second number is called Dark Web, 2015), and the author is now in negotiations to make a movie with the character.

The writing in the mixed perspective of the character and an omniscient narrator resembles the works of José Padilha in the movie Tropa de Elite (Elite Squad, 2007), creates a world where there is a clear separation of inherently corrupt politicians and presumably legitimated vigilantes. Only a more refined reading leads one to realize that the Congress is the place for the birth of both the corruption webs and the desires of the avenging vigilante. In this way one can avoid the easier reading, that vigilante violence and is a just means to end corruption. Here, the monopolies of the place of speech are much more represented than potentially criticized. At the same time, the fictional character of the story, even though referencing actual events, helps one to take this critical position towards the normative ideas contained in the work.

49. See the Guardian story on O Doutrinador in: http://www.theguardian.com/world/2016/mar/27/ brazil-comic-the-awakening-government-scandal-petrobras (last access April 4, 2016). 


\section{CONCLUSIONS: “STEPPING IN THE OFFENDER'S SHOES” WITH A POLITICAL NOTION OF TRANSLATION}

The previous analysis of the literary and comics works on Brazilian dictatorship aimed to verify in which sense these works can help explore the most important traits of the monopolies of the place of speech, resulting from cultural traumas and other segregated social dynamics. The works that were able to reveal these traits and their possibility of critique stood in between more direct and indirect, one-sided and plural, representative and critical perspectives to experiences of trauma. In this way they gave light to the elements of inaccessibility, displacement and belatedness that are constitutive of trauma narratives, as well as of other forms of communication and cultural production. Trauma only reveals more deeply how inaccessible nature in fact is, and how our belated representations of it are always signs of our connections with the others and the world.

With aid on Benjamin's "The Task of the Translator" (1923),,$^{50}$ one can attempt to face the unending process of having to relate to the antagonistic references that we share with each other in our socialization processes.

If we follow Benjamin, the task demands both freedom and deep affection by the foreign, in a way that our representation of it reflects the foreign way of meaning. It is a longing for complementation and understanding more than justifying, if one can ever be separated from the other. The original and the translation, phrase and paraphrase, become fragments of a greater human language that is bound by and affective and ethical drives. The underlying challenge is to never lose sight to the fact that our identities and categories of perception are somehow internally and deeply bound to those (or who) that are opposite or different from us, although we inevitably fool ourselves in believing otherwise.

Vitor Blotta é Professor da Escola de Comunicações e Artes da Universidade de São Paulo.

50. Benjamin, W. “The Task of the Translator”. In: Bullock, M.; Jennings, M. W. (eds). Walter Benjamin. Selected Writings 1913-1926. Cambridge: Harvard University, 1967 [1923].

132 - BLOTTA, Vitor. "You will never understand": the monopoly of the place of speech 